\title{
NOTICE
}

\section{INTERNATIONAL COMMISSION ON ZOOLOGICAL NOMENCLATURE}

In accordance with a decision of the 13th International Congress of Zoology, 1948, public notice is hereby given of the possible use by the International Commission on Zoological Nomenclature of its plenary powers in connection with the following cases, full details of which will be found in Bulletin of Zoological Nomenclature.

Vol. 21, Part 3, published on 7th August, 1964 :-

Designation of a type-species for Lingula Bruguière, [1797] (Brachiopoda). Z.N.(S.) 1598 ;

Designation of type-species for Purpura Bruguière, 1789, and Muricanthus Swainson, 1840; validation of Ocenebra Gray, 1847 ; validation of THAISIDAE Suter, 1913 (Gastropoda). Z.N.(S.) 1621 ;

Vol. 21, Part 4 to be published on 10th October 1964 :-

Designation of a neotype for Belemnites mucronatus Link, 1807 (Cephalopoda). Z.N.(S.) 1160 ;

Suppression of the specific name Echinus rosaceus Linnaeus, 1758, 1764, 1767 and Gmelin, 1788 and of the generic name Echinanthus Leske, 1778 (Echinoidea). Z.N.(S.) 1616;

Suppression of Nana Schumacher, 1817 (Gastropoda). Z.N.(S.) 1622 ;

Validation of Ambalodus Branson and Mehl, 1933 (Conodont). Z.N.(S.) 1633 ;

Any palaeozoologist who wishes to comment on any of the above cases should do so in writing, and in duplicate, as soon as possible, and in any case before 7th February, 1965, for Vol. 21, Part 3 and before 16th April, 1965, for Vol. 21, Part 4. Each comment should bear the reference number of the case in question.

All communications should be addressed to :-

The Secretary,

International Commission on Zoological Nomenclature, c/o British Museum (Natural History),

Cromwell Road,

London, S.W. 7.

England. 